\title{
Nonalcoholic Fatty Liver Disease in Non-Obese Subjects With Abdominal Obesity is Associated With A Higher Risk of Advanced Cardiovascular Disease: A 14 Year Prospective Cohort Study
}

Mi Kyoung Son

Korea National Institute of Health

Ji Hye Park

Korea National Institute of Health

Joung-won Lee

Korea National Institute of Health

Seungwoo Kim

Korea National Institute of Health

Won Ho Kim ( $\sim$ jhkwh@nih.go.kr)

Korea National Institute of Health https://orcid.org/0000-0002-4849-472X

Original investigation

Keywords: non-alcoholic fatty liver disease, cardiovascular disease, abdominal obesity

Posted Date: September 16th, 2020

DOI: https://doi.org/10.21203/rs.3.rs-74194/v1

License: (c) (i) This work is licensed under a Creative Commons Attribution 4.0 International License. Read Full License 


\section{Abstract}

Background Obese nonalcoholic fatty liver disease (NAFLD) is closely associated with an increased risk of cardiovascular disease (CVD). However, the association between non-obese NAFLD and the incidence of CVD is still unclear and little is known about deleterious factors related to their inter-relationship. Here, we investigated the effects of abdominal obesity (AO) and/or NAFLD on CVD risk.

Methods We enrolled 8,422 patients who did not have CVD or consume excessive amounts of alcohol at baseline from the Korean Genome and Epidemiology Study (KoGES). NAFLD was defined using the Fatty Liver Index (FLI). Obesity was defined as a body mass index (BMI) $\geq 25 \mathrm{~kg} / \mathrm{m}^{2}$, and $\mathrm{AO}$ was defined as a waist circumference $(\mathrm{WC}) \geq 90 \mathrm{~cm}$ in men and $\geq 85 \mathrm{~cm}$ in women. Subjects were sub-divided into eight groups depending on whether they were obese, $\mathrm{AO}$, and/or NAFLD.

Results In the full cohort, during a median 11.6 years of follow-up period, the incidence rate (IR) of CVD was $8.07 \%$. The IR of CVD in participants with NAFLD was 1.9-fold higher than in those without NAFLD. The IR per 1,000 person-years for CVD was highest in the non-obese abdominal obesity subjects with NAFLD (15.76 [95\% confidence interval (Cl), 11.76-20.69]). Compared with participants who did not have obesity, AO, or NAFLD, the adjusted hazard ratio for CVD was 1.67 (95\% Cl: 1.16-2.41) in non-obese NAFLD patients with AO, 1.60 (95\% Cl: 1.21-2.11) in NAFLD patients with obesity and AO, and 0.54 (95\% Cl: $0.32-$ 0.91 ) in obese subjects without either NAFLD or AO.

Conclusions The co-occurrence of AO with NAFLD appears to be strongly associated with an increased risk of CVD regardless of obesity; but its risk is higher in non-obese subjects. By contrast, obese individuals without AO or NAFLD appear to be at lower risk. Therefore, early prevention and control of AO and NAFLD is an important means of reducing the risk of CVD, even in subjects with a normal BMI.

\section{Background}

Non-alcoholic fatty liver disease (NAFLD) is the most common chronic liver disease worldwide, and it occurs in individuals of all ages and ethnic groups (1, 2). The prevalence of NAFLD has increased rapidly in recent years with increases in the obesity, aging, and a westernized lifestyle in a number of regions including Asia and has resulted in a surge of health problems. NAFLD progresses silently to nonalcoholic steatohepatitis (NASH), a severe form of NAFLD with varying degrees of inflammation and fibrosis, and can lead to cirrhosis, portal hypertension, and liver-related death in early adulthood (1, 3). In addition, NAFLD is closely associated not only with an increased incidence of liver-related morbidity and mortality, but also with an increased risk of cardiovascular disease (CVD). As well, most patients with NAFLD also display obesity and/or insulin resistance-related metabolic aberrations such as impaired glucose homeostasis, dyslipidemia, hypertension, and low-grade inflammation (3-7). Accordingly, the increase in the prevalence of NAFLD is associated with a growing number of cardio-metabolic derangements. It seems likely that NAFLD co-exists with obesity in a large number of patients and this association increases the risk of CVD; however, the association between CVD risk and obesity or obesity-induced metabolic abnormalities remains controversial.

As aforementioned, obesity is the most notable morbidity with the potential to explain the pathophysiological link between NAFLD and CVD, but not all obese subjects always have metabolic abnormalities. Longitudinal studies investigating the outcomes for an increased risk of CVD in obese population have yielded inconsistent results. Numerous early studies showed either no increase or a slightly higher increase in the risk of developing CVD in obese subjects with metabolically healthy $(\mathrm{MH})$ compared with non-obese subjects with $\mathrm{MH}(8)$, whereas more recent meta-analysis in eight longitudinal studies demonstrated an increased risk of all-cause and CVD mortality in MH obese subjects (9-11). Similarly, non-obese subjects with metabolically unhealthy (MUH) status were also associated with a higher risk of CVD and its associated mortality than obese subjects with $\mathrm{MH}$. This difference in cardio-metabolic outcomes between obese and non-obese subjects is considered to be due to obese and non-obese subjects having different metabolic processes and/or other obesity-independent cardio-metabolic risk factors for incident CVD. Therefore, NAFLD is now regarded as a potential CVD risk factor, independent of obesity and other established risk factors; however, a direct association between NAFLD with or without obesity and CVD comorbidity has not yet been clearly established. As well, most studies of the association between NAFLD and poor cardiovascular outcomes have been conducted in Western populations, with little or no evidence for this association in Asian populations, who have a lower body mass index (BMI) than Caucasians. Additionally, evidence for a link between NAFLD with or without obesity and incident CVD is sparse, even in Western countries.

The prevalence of NAFLD across the globe varies, which may be due to lifestyle, age, sex, or ethnic differences. The overall prevalence of NAFLD in Asia is $28.5 \%$. In Korea, a cohort study revealed a $27 \%$ prevalence of NAFLD $(12,13)$. However, few studies have been performed on the risk of CVD in NAFLD Korean subjects with or without associated obesity. Interestingly, recent studies have proposed that NAFLD is more closely associated with insulin resistance than with metabolic syndrome even after adjusting for BMI and metabolic components, supporting previous observations that fatty liver is a major determinant of insulin resistance independent of obesity, a well-known regulator of insulin resistance. Although BMI has been used as a standard to define obesity in clinical and public health guidelines, it does not distinguish individuals who differ in body shape or body fat distribution. The prognostic value of obesity as defined by BMI for cardio-metabolic disorders, including diabetes and CVD, is a subject of debate and is being seriously challenged, especially in the relatively nonobese Asian population. Thus, the demand for new prognostic indicators other than BMI is increasing. Recently, abdominal obesity (AO) was reported to be a novel indicator of obesity and closely associated with NAFLD. The waist circumference (WC), an anthropometric measure of obesity, is also a measure of AO, which is currently proposed to be a better predictor and/or discriminator for cardio-metabolic diseases than BMI $(14,15)$. However, few studies to date have been performed in obese or non-obese subjects with NAFLD and/or AO to evaluate their impact on the risk of CVD (16-19). Thus, it is necessary to establish a comprehensive and accurate strategy to predict and discriminate CVD risk at an earlier stage of cardio-metabolic derangement, even before NAFLD or CVD onset.

In this study, we investigated the incidence and risk of CVD according to the absence/presence of NAFLD, obesity, and AO in a longitudinal study of a prospective Korean cohort. We also evaluated the impact of $\mathrm{AO}$, a subclinical cardio-metabolic risk factor, on the risk of incident $\mathrm{CVD}$ in obese or non-obese subjects with NAFLD. 


\section{Methods}

\section{Data source}

Data were obtained from the Korean Genome and Epidemiology Study (KoGES), which is an ongoing, prospective, community-based cohort study that began in 2001. The aim of the KoGES is to determine the relationships between genetic, environmental, and lifestyle determinants of chronic diseases, such as diabetes mellitus, cerebrovascular disease, and hypertension, in Korean people (20). The participants are residents of both urban (Ansan) and rural (Anseong) areas. Enrollment in the study was based on the characteristics of the community and the most efficient method for the recruitment of a representative sample of the Korean population. Initially, the cohort comprised 10,030 participants that were 40-69 years of age between 2001 and 2002 . Follow-up examinations were conducted biennially between 2003 and 2014. All the participants provided their written informed consent. The study protocol was approved by the Institutional Review Board of the Korea Centers for Disease Control and Prevention (no. 2018-02-02-2C-A).

\section{Study variables}

Body mass index (BMI) was calculated as body mass in kilograms divided by height in meters squared. Waist circumference (WC) was measured at the midpoint between the lower ribs and the top of the iliac crest in the standing position. Abdominal obesity was defined as a WC $>85 \mathrm{~cm}$ in $w o m e n$ and $>90 \mathrm{~cm}$ in men (21). Obesity was defined as a BMI $\geq 25 \mathrm{~kg} / \mathrm{m}^{2}$, in accordance with the World Health Organization criteria for individuals of Asian descent (22).

NAFLD was assessed using the fatty liver index $(F L I)$ as a non-invasive marker, which was calculated using the published formula: FLI $=e^{L} /\left(1+e^{L}\right) \times 100$, where $L=0.953 \times \log _{\mathrm{e}}$. Triglycerides $(\mathrm{TG} ; \mathrm{mg} / \mathrm{dl})+0.139 \times \mathrm{BMI}\left(\mathrm{kg} / \mathrm{m}^{2}\right)+0.718 \times \log _{\mathrm{e}}$ gamma-glutamyltranspeptidase activity $(\mathrm{GGT} ; \mathrm{U} / \mathrm{l})+0.053 \times \mathrm{WC}(\mathrm{cm})-$ 15.745 (23). NAFLD was defined using an FLI $\geq 35$ for men and $\geq 20$ for women; these values were previously suggested to be suitable cut-off values for use in Asian populations (24). The participants were also allocated to eight groups on the basis of their BMI, WC, and NAFLD, as follows: (1) no obesity, abdominal obesity, or NAFLD (O(-)AO(-)NAFLD(-)); (2) no obesity or abdominal obesity, but NAFLD (O(-)AO(-)NAFLD(+)); (3) no obesity or NAFLD, but abdominal obesity (O(-)AO(+)NAFLD(-)); (4) no obesity, but abdominal obesity and NAFLD (O(-)AO(+)NAFLD(+)); (5) obesity, but no abdominal obesity or NAFLD $(\mathrm{O}(+) \mathrm{AO}(-) \mathrm{NAFLD}(-)) ;(6)$ obesity and NAFLD, but no abdominal obesity $(\mathrm{O}(+) \mathrm{AO}(-) \mathrm{NAFLD}(+))$; (7) obesity and abdominal obesity, but no NAFLD $(\mathrm{O}(+) \mathrm{AO}(+) \operatorname{NAFLD}(-))$; and (8) obesity, abdominal obesity, and NAFLD $(\mathrm{O}(+) \mathrm{AO}(+) \operatorname{NAFLD}(+))$.

The primary outcome was the initial diagnosis of CVD by a physician or the issue of a prescription for a CVD-related medication during the follow-up period. "CVD" included myocardial infarction (MI), coronary artery disease (CAD), congestive heart failure (CHF), and stroke/transient ischemic attack (TIA). CVDrelated mortality was not recorded during the present study because information regarding deaths and the causes of death were not available. Therefore, data relating to participants who were lost to follow-up or died were censored at the time of the final survey.

\section{Statistical analysis}

Baseline characteristics relating to obesity, AO, and NAFLD were recorded at baseline. Continuous variables are expressed as means \pm standard deviations and were compared using $t$-tests; categorical variables are expressed as frequencies (percentages) and were compared using chi-square tests.

The incidence rates for the outcome were reported as the number of participants per 1,000 person-years. Kaplan-Meier curves were created for the period of time between baseline and the outcome, according to the presence of obesity, AO, and/or NAFLD, and the survival distributions were compared using the logrank test when the proportional hazard assumption was met. This was tested using scaled Schoenfeld residuals (25).

The relationships between combinations of obesity, AO, and NAFLD, and the incidence of CVD were determined using a Cox proportional hazard regression model, with adjustment for potential confounders (sex, age, geographical area, income, alcohol consumption, smoking, medical history [hypertension, diabetes mellitus, hyperlipidemia, and kidney disease], systolic blood pressure [SBP], diastolic blood pressure [DBP], fasting glucose, albumin, blood urea nitrogen [BUN], creatinine, aspartate aminotransferase [AST], alanine aminotransaminase [ALT], gamma-glutamyltransferase [GGT], total cholesterol, high-density lipoprotein [HDL]-cholesterol, triglyceride, total protein, total bilirubin, calcium, sodium, potassium, chloride, C-reactive protein [CRP], white blood cell [WBC] count, red blood cell [RBC] count, hemoglobin, hematocrit, glycated hemoglobin [HbA1c], platelet count, and renin activity).

All the statistical tests performed were two-tailed and $P<0.05$ was considered to represent statistical significance. Statistical analyses were performed using SAS software (ver. 9.4; SAS Institute, Cary, NC, USA) or R 3.5.3 (R Foundation, Vienna, Austria). The R (http://cran.r-project.org) package "survival" was used to conduct the survival analysis.

\section{Results}

\section{Baseline characteristics of the participants}

Of 10,030 participants enrolled in the KoGES, 292 had CVD at baseline, 409 consumed alcohol excessively (alcohol intake of $\geq 40 \mathrm{~g} /$ day for women and $\geq 60$ $\mathrm{g} /$ day for men (26)), 10 had missing information, and 897 did not complete follow-up. Of the remaining 8,422 participants, 4,110 (48.8\%) had NAFLD, according to FLI at baseline. The participants with and without NAFLD differed at baseline with respect to body shape (BMI and WC). In general, participants with NAFLD were more likely than those without to be diabetic; to have higher fasting glucose; to have higher liver enzyme activities (AST, ALT, and GGT); to have higher total cholesterol, lower HDL-cholesterol, higher TG, higher calcium, lower chloride, and higher CRP concentrations; to have higher hematologic values (WBC count, RBC count, hemoglobin, hematocrit, and platelet count); and to have higher HbA1c (Table 1). 
According to their combinations of obesity, AO, and NAFLD, participants were classified as being O(-)AO(-)NAFLD(-) ( $n=3,498 ; 41.5 \%), O(-) A O(-) N A F L D(+)$ $(n=869 ; 10.3 \%), O(-) A O(+) N A F L D(-)(n=166 ; 2.0 \%), O(-) A O(-) N A F L D(+)(n=309 ; 3.7 \%), O(+) A O(-) N A F L D(-)(n=557 ; 6.6 \%), O(+) A O(-) N A F L D(+)(n=992 ;$ $11.8 \%), O(+) A O(+) \operatorname{NAFLD}(-)(n=91 ; 1.1 \%)$, and $O(+) A O(+) \operatorname{NAFLD}(+)(n=1,940 ; 23.0 \%)$, respectively (Table 1). Among the participants with hypertension or diabetes mellitus, the proportions who were $\mathrm{O}(+) \mathrm{AO}(+) \mathrm{NAFLD}(+)$ were relatively high ( $37.5 \%$ for hypertension and $37.3 \%$ for diabetes mellitus), while the proportions who were $\mathrm{O}(-) \mathrm{AO}(-) \mathrm{NAFLD}(-)$ were relatively low $(24.9 \%$ for hypertension and $20.2 \%$ for diabetes mellitus) (Figure 1$)$. O(+)AO(-)NAFLD(-) was relatively common among urban participants $(9.5 \%)$, and $\mathrm{O}(-) \mathrm{AO}(+) \mathrm{NAFLD}(+)$ was relatively common among participants who were ${ }^{3} 65$ years of age $(7.5 \%)$ or who had diabetes mellitus (7.1\%).

\section{Risks of CVD in participants with each combination of obesity, AO, and NAFLD}

During the follow-up period (median, 11.6 years; IQR, 1.4-12.6 years), 680 (8.1\%) participants developed CVD for the first time (Additional file 1). The incidence of CVD was higher in participants with NAFLD, obesity, or AO than in those without these risk factors (Additional file 2A-C). In particular, participants with both NAFLD and AO had a high incidence of CVD (13.2\%) (Additional file 2E). The incidence of CVD was significantly higher in NAFLD patients with and without obesity than in those without obesity and NAFLD (Additional file 2D), similar to what was reported in a previous study (27).

When stratifying the obesity, AO and NAFLD, the Kaplan-Meier survival analysis also showed that the incidence of CVD significantly differed between participants with the various combinations of body shape and NAFLD (Figure 2). The incidence of CVD in participants who were O(-)AO(+)NAFLD(+) was the highest $(15.76 / 1,000$ person-years), and it was also high in those who were $O(+) A O(+) \operatorname{NAFLD}(+)(14.01 / 1,000$ person-years), whereas those who were $\mathrm{O}(+) \mathrm{AO}(-) \mathrm{NAFLD}(-)$ had the lowest incidence $(2.83 / 1,000$ person-years) (Figure 3 ).

Multivariable analysis, with adjustment for covariates, showed that compared with participants who were $O(-) \operatorname{AO}(-)$ NAFLD(-), those who were $\mathrm{O}(-) \mathrm{AO}(+) \mathrm{NAFLD}(+)$ or $\mathrm{O}(+) \mathrm{AO}(+) \mathrm{NAFLD}(+)$ had significantly higher risks of CVD (hazard ratio [HR]: $1.67,95 \%$ confidence interval [CI]: 1.16-2.41 for the $\mathrm{O}(-) \mathrm{AO}(+) \mathrm{NAFLD}(+)$ group; and HR: $1.60,95 \% \mathrm{Cl}: 1.21-2.11$ for the $\mathrm{O}(+) \mathrm{AO}(+) \mathrm{NAFLD}(+)$ group), but not those without $\mathrm{AO}(\mathrm{O}(-) \mathrm{AO}(-) \mathrm{NAFLD}(+)$ and $\mathrm{O}(+) \mathrm{AO}(-) \mathrm{NAFLD}(+))$, which indicates that the combination of $\mathrm{AO}$ and NAFLD substantially increases the risk of developing CVD regardless of obesity. By contrast, participants who were $\mathrm{O}(+) \mathrm{AO}(-) \mathrm{NAFLD}(-)$ were at significantly lower risk of developing CVD (HR: 0.54, 95\% Cl: 0.32-0.91) (Figure 3).

\section{Risk factors for CVD in participants who were $O(-) A O(+) N A F L D(+)$ or $O(+) A O(+) N A F L D(+)$}

The factors associated with a higher risk of CVD were determined by multiple Cox regression analyses with variable selection, using backward elimination, for the $\mathrm{O}(-) \mathrm{AO}(+) \mathrm{NAFLD}(+)$ and $\mathrm{O}(+) \mathrm{AO}(+) \mathrm{NAFLD}(+)$ groups (Additional file 3 ). After adjustment for covariates, age, hypertension, and HbA1c were significantly associated with CVD in participants who were $\mathrm{O}(-) \mathrm{AO}(+) \mathrm{NAFLD}(+)$. In participants who were $\mathrm{O}(+) \mathrm{AO}(+) \mathrm{NAFLD}(+)$, age, SBP, and HbA1c were significantly associated with a higher risk of CVD. This indicates that appropriate control of blood pressure and HbA1c might be important to prevent CVD in patients with both $A O$ and NAFLD.

\section{Subgroup analyses}

To investigate further whether the stratification of each risk factor affected the risk of CVD incidence in the classified subgroups according to the combination of obese, AO, and NAFLD (Additional file 4), we classified each risk factor into low- and high-risk groups according to its cut-off level. Being $\mathrm{O}(-) \mathrm{AO}(+) \mathrm{NAFLD}(+)$ was significantly associated with a higher risk of CVD, compared with being O(-)AO(-)NAFLD(-), in patients who were $\geq 60$ years old, who were hypertensive, who had an $\mathrm{HbA} 1 \mathrm{c}>5.6 \%$, who had a total cholesterol $\geq 200 \mathrm{mg} / \mathrm{dL}$, who had low and high levels of HDL-cholesterol, and who had a platelet count $\leq 261 \times 10^{3} / \mu \mathrm{L}$. On the other hand, subjects with $\mathrm{O}(+) \mathrm{AO}(+) \mathrm{NAFLD}(+)$, compared with those who were $\mathrm{O}(-) \mathrm{AO}(-) \mathrm{NAFLD}(-)$, had a significantly higher risk of CVD in both low and high-risk groups for hypertension, HbA1c, HDL-cholesterol and platelet count. However, there were no significant interactions of age, sex, geographical area, hypertension, HbA1c, total cholesterol, HDL-cholesterol, or platelet count with the various combinations of obesity, $\mathrm{AO}$, and NAFLD, with respect to the incidence of CVD.

\section{Discussion}

The results of this prospective cohort study, which included a long follow-up period, indicate that patients who are $O(-) A O(+) N A F L D(+)$ are at a relatively high risk of CVD, and their level of risk is similar to that of patients who are $O(+) A O(+) N A F L D(+)$. Interestingly, we found that participants who were $\mathrm{O}(+) \mathrm{AO}(-) \mathrm{NAFLD}(-)$ in the present study were at the lowest risk of developing CVD. The proportion of the participants who were $\mathrm{O}(-) \mathrm{AO}(+) \mathrm{NAFLD}(+)$ was high among those who were ${ }^{3} 65$ years old or those who had diabetes mellitus, whereas the proportion of participants who were $\mathrm{O}(+) \mathrm{AO}(+) \mathrm{NAFLD}(+)$ was high among those who had hypertension or diabetes mellitus. To our knowledge, this is the first study to compare the risks of CVD among patients with combinations of obesity, AO, and NAFLD in Korea.

\section{NAFLD, obesity, and AO in South Korea}

The prevalence of NAFLD, obesity, and AO varies between ethnic groups. NAFLD affects up to 30\% of the adult population in the United States and Europe (13), and around 25\% in Asia (28). By contrast, in South Korea, the prevalence of NAFLD, assessed using the controlled attenuation parameter of transient elastography, a non-invasive tool that estimates the severity of liver fibrosis and steatosis, is $42.9 \%$ in the healthy population (29). In the present study, the prevalence of NAFLD, obesity, and AO was $48.8 \%, 42.5 \%$, and $29.8 \%$, respectively. These discrepancies in the estimated prevalence of NAFLD may be the result of variations in the definitions and inclusion criteria used for NAFLD in each study population. However, the prevalence of NAFLD, obesity, and AO is increasing because of the aging population, obesity, low physical activity, and Westernization of the lifestyle in South Korea (28, 30, 31). Indeed, the Korea National Health and Nutrition Examination Survey (KNHANES) has shown that the prevalence of NAFLD, defined as a hepatic steatosis index $>36$, increased from $18.6 \%$ in $1998-2001$ to $21.5 \%$ in $2016-2017$, and during the same period the prevalence of obesity and AO also increased (from $27.0 \%$ to $35.1 \%$ for obesity, 
and from $29.4 \%$ to $36.0 \%$ for AO) (32). Therefore, the prevalence of NAFLD, obesity, and AO in Korea is expected to increase further, and these conditions will represent a significant public health burden in the near future.

\section{Relationships between NAFLD, obesity, and AO, and cardiovascular risk}

NAFLD is a chronic disease that is characterized by fat accumulation and inflammation in the liver; therefore, individuals who are obese and/or have AO are at the greatest risk of developing NAFLD. In addition, the majority of NAFLD patients die from cardiovascular disease (33). Obesity is generally defined as a state of abnormal or excessive accumulation of adipose tissue, which predisposes to a variety of health problems that are associated with cardio-metabolic abnormalities. BMI is the measure that is normally used to define obesity in clinical and public health guidelines, and high BMI has served as a proxy for general overweight and obesity for many years (16-19). However, AO, defined using WC, more effectively reflects visceral fat content, and this is more strongly associated with the risk of CVD $(34,35)$. In the present study, participants with NAFLD and/or AO had a significantly higher risk of CVD, independent of obesity (Additional file 2). Recent studies have also shown that central obesity in individuals with a normal BMl is strongly associated with a higher risk of all-cause and CVD mortality (36-38). In contrast to individuals with obesity, the relationship between NAFLD and the risk of CVD in people with a normal BMI remains to be fully elucidated. In Japan, normal-weight individuals with NAFLD have a higher risk of incident CVD than overweight individuals (27); however, in Korea, non-obese NAFLD is not significantly associated with a higher risk of incident CVD (39). Based on these results, obesity defined by BMI criteria does not always entail metabolic abnormalities and CVD risk. Indeed, a previous study reported a subgroup of obese individuals who lacked relevant cardio-metabolic risk factors had a reduced risk of CVD $(40,41)$. Therefore, a novel indicator is needed to access cardio-metabolic abnormalities including diabetes and CVD risk in individuals regardless of their BMI, particularly in Asian subjects, who tend to have a low BMI. Abdominal obesity is closely associated with NAFLD and can easily be assessed by measuring waist circumference (WC), an anthropometric measure of obesity. Abdominal obesity is now considered a potential prognostic indicator of development of NAFLD, diabetes, and CVD; and metabolically classification of obesity defined by WC criteria could provide more accurate information for predicting incident CVD risk. However, information on CVD risk according to combinations of BMI, WC and NAFLD is limited and to the best of our knowledge, this is the first study to compare the risk of CVD incidence according to the combination of abdominal obesity and NAFLD between obese and non-obese subjects, in particular, Koreans.

\section{Effects of combinations of obesity and NAFLD on cardiovascular risk}

In the present study, participants who had AO but not generalized obesity were at significantly higher risk of CVD than those who were obese, but did not have AO, although the statistical significance disappeared in multivariable analysis with adjustment for covariates including NAFLD (Additional file 2F). In addition, the effect of NAFLD on cardiovascular risk depended on body shape: it was associated with a 1.67-fold higher risk of CVD in the O(-)AO(+)NAFLD(+) group, but not in the $\mathrm{O}(-) \mathrm{AO}(+) \mathrm{NAFLD}(-)$ group, when they were compared with the $\mathrm{O}(-) \mathrm{AO}(-) \mathrm{NAFLD}(-)$ group. Interestingly, being $\mathrm{O}(+) \mathrm{AO}(-) \mathrm{NAFLD}(-)$ was significantly associated with a lower risk of developing CVD. Although the reasons for the higher risk in the O(-)AO(+)NAFLD(+) group and the lower risk in the $\mathrm{O}(+) \mathrm{AO}(-) \mathrm{NAFLD}(-)$ group are unclear, we can speculate that (1) AO, but not generalized obesity, is associated with both excess visceral fat and low muscle mass $(42,43)$, which are associated with risk factors for CVD such as insulin resistance, hyperinsulinemia, dyslipidemia, and inflammation (44-46); (2) NAFLD plays a crucial role in the pathogenesis of CVD via the systemic release of several proinflammatory, prothrombotic, and oxidative stress mediators (33).

Conversely, individuals who are $\mathrm{O}(+) \mathrm{AO}(-) \mathrm{NAFLD}(-)$ may have a larger amount of gluteofemoral adipose tissue, which is associated with a favorable metabolic and cardiovascular risk profile, and it could partially explain the obesity paradox $(47,48)$. In general, individuals who are determined to have a normal weight on the basis of BMI are considered to be normal, regardless of whether they have central obesity, in clinical practice. However, the present findings indicate that WC should also be measured and used in conjunction with BMI in the assessment of obesity to improve the assessment and prediction of potential cardio-metabolic risks and to provide an accurate prognosis with regard to the risk of CVD. In addition, individuals at high risk for CVD can be identified by considering which combination of obesity, AO, and NAFLD they have. Furthermore, the present results suggest that efforts aimed at reducing the incidences of $A O$ and NAFLD in both non-obese and obese individuals might delay or prevent the development of CVD. We hope that the present findings could lead to the establishment of a comprehensive and accurate strategy for the appropriate management of patients in the early stages of cardio-metabolic derangement to prevent the development of CVD.

\section{Strengths and limitations}

This study had several limitations that need to be addressed. First, NAFLD was defined on the basis of FLI, which may have led to some exposure misclassification. Liver biopsy, and non-invasive techniques such as ultrasonography, magnetic resonance spectroscopy (MRS), and computed tomography (CT), for the assessment of fatty liver were not available in the present study; therefore, we used FLI, which is a well-validated tool for the diagnosis of NAFLD (23). The Asian population tends to have a higher prevalence of NAFLD and metabolic syndrome than other populations despite having low BMIs. This has been reported to be due to the high prevalence of central adiposity in this population $(49,50)$. Therefore, the optimal cut-off values for FLI in Asian people remain controversial. To overcome these limitations, we used FLI cut-offs ( $\geq 35$ for men and $\geq 20$ for women) for the diagnosis of NAFLD that were suggested to be suitable for use in Asian people in a previous study (24). However, we also compared the findings obtained using these cut-off values with those obtained using other FLI cut-off values (both $\geq 30$ and $\geq 60$ ) that have been previously reported (23) and generated similar results (Additional file 5 ). Second, it is possible that there were additional confounders that were not accounted for in the study, despite the fact that we adjusted for numerous variables, including demographic characteristics, drinking status, smoking status, medical history, blood pressure, and laboratory parameters. Third, CVD mortality information could not be obtained for this analysis; therefore, we may have underestimated the risk of CVD.

However, the study had several strengths. The main strengths were its community-based prospective design and the long follow-up period. In addition, to our knowledge, this is the first study to investigate the long-term impact of combinations of obesity, AO, and NAFLD on the risk of CVD in South Korea.

\section{Conclusions}


In conclusion, in this prospective cohort study of 8,422 subjects, the combination of AO and NAFLD in non-obese subjects was found to be closely associated with an increased risk of CVD, similar to that of obese subjects with AO and NAFLD. Based on these data, we suggest that FLI-defined NAFLD subjects have a poor cardio-metabolic health status that deteriorates if it is associated with AO. Therefore, in order to effectively reduce the risk of CVD incidence, it is necessary to prevent and control the occurrence of AO in NAFLD patients, even in individuals with a normal BMI as well as in obese subjects.

\section{List Of Abbreviations}

NAFLD, non-alcoholic fatty liver disease; CVD, cardiovascular disease; BMI, body mass index; WC, waist circumference; AO, abdominal obesity; KoGES, Korean Genome and Epidemiology Study; FLI, fatty liver index; TG, triglycerides; O(-)AO(-)NAFLD(-), no obesity, abdominal obesity, or NAFLD; O(-)AO(-)NAFLD(+), NAFLD, but no obesity or abdominal obesity; O(-)AO(+)NAFLD(-), abdominal obesity, but no generalized obesity or NAFLD; O(-)AO(+)NAFLD(+), abdominal obesity and NAFLD, but no generalized obesity; O(+)AO(-)NAFLD(-), obesity, but no abdominal obesity or NAFLD; O(+)AO(-)NAFLD(+), obesity and NAFLD, but no abdominal obesity; $\mathrm{O}(+) \mathrm{AO}(+) \mathrm{NAFLD}(-)$, obesity and abdominal obesity, but no NAFLD; O(+)AO(+)NAFLD(+), obesity, abdominal obesity, and NAFLD; MI, myocardial infarction; $\mathrm{CAD}$, coronary artery disease; $\mathrm{CHF}$, congestive heart failure; TIA, transient ischemic attack; BUN, blood urea nitrogen; $\mathrm{AST}$, aspartate aminotransferase; ALT, alanine aminotransaminase; GGT, gamma-glutamyltransferase; HDL-cholesterol, high-density lipoprotein cholesterol; CRP, C-reactive protein; WBC, white blood cell; RBC, red blood cell; HbA1c, glycated hemoglobin; IGT, impaired glucose tolerance; SBP, systolic blood pressure; DBP, diastolic blood pressure; HR, hazard ratio; Cl, confidence interval; KNHANES, Korea National Health and Nutrition Examination Survey.

\section{Declarations}

\section{Ethics approval and consent to participate}

All participants signed the informed consent form. The study protocol was approved by the Institutional Review Board of the Korea Centers for Disease Control and Prevention (no. 2018-02-02-2C-A).

\section{Consent for publication}

Not applicable.

\section{Availability of data and materials}

The KoGES data will be made available following the submission of an application form, together with documents such as a research plan and IRB approval form, to the Korea Centers for Disease Control and Prevention (KCDC). The relevant data request process and contact information can be found by following this link: http://www.nih.go.kr/contents.es?mid=a50401010400\#menu4_1_2.

\section{Competing interests}

The authors declare no competing interests.

\section{Funding}

This study was supported by an intramural research grant from the Korea National Institute of Health, 4800-4845-302 (2018-NI007-01 and 2020-NI028-00).

\section{Authors' contributions}

M.K.S. participated in the design of the study, performed the statistical analysis, interpreted the findings, and drafted the manuscript. W.H.K. participated in the design of the study, revised the manuscript, discussed important intellectual content, and provided final approval for the version to be published.

\section{Acknowledgments}

Not applicable.

\section{References}

1. Lonardo A, Bellentani S, Argo CK, Ballestri S, Byrne CD, Caldwell SH, et al. Epidemiological modifiers of non-alcoholic fatty liver disease: Focus on high-risk groups. Dig Liver Dis. 2015;47(12):997-1006.

2. Rinella ME. Nonalcoholic fatty liver disease: a systematic review. JAMA. 2015;313(22):2263-73.

3. Anstee QM, Targher G, Day CP. Progression of NAFLD to diabetes mellitus, cardiovascular disease or cirrhosis. Nat Rev Gastroenterol Hepatol. 2013;10(6):330-44.

4. Ballestri S, Lonardo A, Bonapace S, Byrne CD, Loria P, Targher G. Risk of cardiovascular, cardiac and arrhythmic complications in patients with nonalcoholic fatty liver disease. World J Gastroenterol. 2014;20(7):1724-45.

5. Ballestri S, Zona S, Targher G, Romagnoli D, Baldelli E, Nascimbeni F, et al. Nonalcoholic fatty liver disease is associated with an almost twofold increased risk of incident type 2 diabetes and metabolic syndrome. Evidence from a systematic review and meta-analysis. J Gastroenterol Hepatol. 2016;31(5):93644.

6. Byrne CD, Targher G. NAFLD: a multisystem disease. J Hepatol. 2015;62(1 Suppl):S47-64. 
7. Targher G, Day CP, Bonora E. Risk of cardiovascular disease in patients with nonalcoholic fatty liver disease. N Engl J Med. 2010;363(14):1341-50.

8. Hamer M, Stamatakis E. Metabolically healthy obesity and risk of all-cause and cardiovascular disease mortality. J Clin Endocrinol Metab. 2012;97(7):2482-8.

9. Khan UI, Wang D, Thurston RC, Sowers M, Sutton-Tyrrell K, Matthews KA, et al. Burden of subclinical cardiovascular disease in "metabolically benign" and "at-risk" overweight and obese women: the Study of Women's Health Across the Nation (SWAN). Atherosclerosis. 2011;217(1):179-86.

10. Kramer CK, Zinman B, Retnakaran R. Are metabolically healthy overweight and obesity benign conditions?: A systematic review and meta-analysis. Ann Intern Med. 2013;159(11):758-69.

11. Jung CH, Lee MJ, Hwang JY, Jang JE, Leem J, Yang DH, et al. Association of metabolically healthy obesity with subclinical coronary atherosclerosis in a Korean population. Obesity (Silver Spring). 2014;22(12):2613-20.

12. Chang Y, Jung HS, Yun KE, Cho J, Cho YK, Ryu S. Cohort study of non-alcoholic fatty liver disease, NAFLD fibrosis score, and the risk of incident diabetes in a Korean population. Am J Gastroenterol. 2013;108(12):1861-8.

13. Li J, Zou B, Yeo YH, Feng Y, Xie X, Lee DH, et al. Prevalence, incidence, and outcome of non-alcoholic fatty liver disease in Asia, 1999-2019: a systematic review and meta-analysis. Lancet Gastroenterol Hepatol. 2019;4(5):389-98.

14. Angulo P. Nonalcoholic fatty liver disease. N Engl J Med. 2002;346(16):1221-31.

15. Keihani S, Hosseinpanah F, Barzin M, Serahati S, Doustmohamadian S, Azizi F. Abdominal obesity phenotypes and risk of cardiovascular disease in a decade of follow-up: the Tehran Lipid and Glucose Study. Atherosclerosis. 2015;238(2):256-63.

16. Højgaard B, Gyrd-Hansen D, Olsen KR, Søgaard J, Sørensen TI. Waist circumference and body mass index as predictors of health care costs. PLoS One. 2008;3(7):e2619.

17. Staiano AE, Reeder BA, Elliott S, Joffres MR, Pahwa P, Kirkland SA, et al. Body mass index versus waist circumference as predictors of mortality in Canadian adults. Int J Obes (Lond). 2012;36(11):1450-4.

18. Lee JW, Lim NK, Baek TH, Park SH, Park HY. Anthropometric indices as predictors of hypertension among men and women aged $40-69$ years in the Korean population: the Korean Genome and Epidemiology Study. BMC Public Health. 2015;15:140.

19. Li R, Shi L, Jia J, Li Y, Yang Q, Ruan Y, et al. Differentiating the associations of waist circumference and body mass index with cardiovascular disease risk in a Chinese population. Asia Pac J Public Health. 2015;27(2):NP457-67.

20. Kim Y, Han BG, group K. Cohort Profile: The Korean Genome and Epidemiology Study (KoGES) Consortium. Int J Epidemiol. 2017;46(2):e20.

21. Consultation WE. Appropriate body-mass index for Asian populations and its implications for policy and intervention strategies. Lancet. 2004;363(9403):157-63.

22. obesity laftso. The Asia-Pacific perspective: redefining obesity and its treatment: World Health Organization Western Pacific Region; 2000.

23. Bedogni G, Bellentani S, Miglioli L, Masutti F, Passalacqua M, Castiglione A, et al. The Fatty Liver Index: a simple and accurate predictor of hepatic steatosis in the general population. BMC Gastroenterol. 2006;6:33.

24. Yang BL, Wu WC, Fang KC, Wang YC, Huo TI, Huang YH, et al. External validation of fatty liver index for identifying ultrasonographic fatty liver in a largescale cross-sectional study in Taiwan. PLoS One. 2015;10(3):e0120443.

25. D S. Partial residuals for the proportional hazards regression model. Biometrika. 1982;69:239-41.

26. Kim JH, Jung DH, Kwon YJ, Lee JI, Shim JY. The impact of the sleep duration on NAFLD score in Korean middle-aged adults: a community-based cohort study. Sleep Med. 2019;57:144-50.

27. Yoshitaka H, Hamaguchi M, Kojima T, Fukuda T, Ohbora A, Fukui M. Nonoverweight nonalcoholic fatty liver disease and incident cardiovascular disease: A post hoc analysis of a cohort study. Medicine (Baltimore). 2017;96(18):e6712.

28. Fan JG, Kim SU, Wong VW. New trends on obesity and NAFLD in Asia. J Hepatol. 2017;67(4):862-73.

29. Lee HW, Kim BK, Kim SU, Park JY, Kim DY, Ahn SH, et al. Prevalence and Predictors of Significant Fibrosis Among Subjects with Transient ElastographyDefined Nonalcoholic Fatty Liver Disease. Dig Dis Sci. 2017;62(8):2150-8.

30. Kang HT, Shim JY, Lee HR, Park BJ, Linton JA, Lee YJ. Trends in prevalence of overweight and obesity in Korean adults, 1998-2009: the Korean National Health and Nutrition Examination Survey. J Epidemiol. 2014;24(2):109-16.

31. Lim J, Park HS. Trends in the prevalence of underweight, obesity, abdominal obesity and their related lifestyle factors in Korean young adults, $1998-2012$. Obes Res Clin Pract. 2018;12(4):358-64.

32. Park SH, Plank LD, Suk KT, Park YE, Lee J, Choi JH, et al. Trends in the prevalence of chronic liver disease in the Korean adult population, 1998-2017. Clin Mol Hepatol. 2020;26(2):209-15.

33. Lim S, Taskinen MR, Borén J. Crosstalk between nonalcoholic fatty liver disease and cardiometabolic syndrome. Obes Rev. 2019;20(4):599-611.

34. Fan H, Li X, Zheng L, Chen X, Lan Q, Wu H, et al. Abdominal obesity is strongly associated with Cardiovascular Disease and its Risk Factors in Elderly and very Elderly Community-dwelling Chinese. Sci Rep. 2016;6:21521.

35. Schneider HJ, Friedrich N, Klotsche J, Pieper L, Nauck M, John U, et al. The predictive value of different measures of obesity for incident cardiovascular events and mortality. J Clin Endocrinol Metab. 2010;95(4):1777-85.

36. Hamer M, O'Donovan G, Stensel D, Stamatakis E. Normal-Weight Central Obesity and Risk for Mortality. Ann Intern Med. 2017;166(12):917-8.

37. Sahakyan KR, Somers VK, Rodriguez-Escudero JP, Hodge DO, Carter RE, Sochor O, et al. Normal-Weight Central Obesity: Implications for Total and Cardiovascular Mortality. Ann Intern Med. 2015;163(11):827-35. 
38. Sun Y, Liu B, Snetselaar LG, Wallace RB, Caan BJ, Rohan TE, et al. Association of Normal-Weight Central Obesity With All-Cause and Cause-Specific Mortality Among Postmenopausal Women. JAMA Netw Open. 2019;2(7):e197337.

39. Kim SS, Cho HJ, Kim HJ, Kang DR, Berry JR, Kim JH, et al. Nonalcoholic fatty liver disease as a sentinel marker for the development of diabetes mellitus in non-obese subjects. Dig Liver Dis. 2018;50(4):370-7.

40. Lavie CJ, De Schutter A, Milani RV. Healthy obese versus unhealthy lean: the obesity paradox. Nat Rev Endocrinol. 2015;11(1):55-62.

41. Guo F, Garvey WT. Cardiometabolic disease risk in metabolically healthy and unhealthy obesity: Stability of metabolic health status in adults. Obesity (Silver Spring). 2016;24(2):516-25.

42. Keevil VL, Luben R, Dalzell N, Hayat S, Sayer AA, Wareham NJ, et al. Cross-sectional associations between different measures of obesity and muscle strength in men and women in a British cohort study. The Journal of Nutrition Health \& Aging. 2015;19(1):3-11.

43. Kim SK, Park SW, Kim SH, Cha BS, Lee HC, Cho YW. Visceral fat amount is associated with carotid atherosclerosis even in type 2 diabetic men with a normal waist circumference. International Journal of Obesity. 2009;33:131-5.

44. Després JP. Intra-abdominal obesity: an untreated risk factor for type 2 diabetes and cardiovascular disease. J Endocrinol Invest. 2006;29(3):77-82.

45. Kim K, Park SM. Association of muscle mass and fat mass with insulin resistance and the prevalence of metabolic syndrome in Korean adults: a crosssectional study. Scientific Reports. 2018;8:2703.

46. Navab M, Anantharamiaiah GM, Fogelman AM. The role of high-density lipoprotein in inflammation. Trends Cardiovasc Med. 2005;15(4):158-61.

47. Lavie CJ, McAuley PA, Church TS, Milani RV, Blair SN. Obesity and cardiovascular diseases: implications regarding fitness, fatness, and severity in the obesity paradox. J Am Coll Cardiol. 2014;63(14):1345-54.

48. Wannamethee SG, Shaper AG, Whincup PH, Lennon L, Papacosta O, Sattar N. The obesity paradox in men with coronary heart disease and heart failure: the role of muscle mass and leptin. Int J Cardiol. 2014;171(1):49-55.

49. Koehler EM, Schouten JN, Hansen BE, van Rooij FJ, Hofman A, Stricker BH, et al. Prevalence and risk factors of non-alcoholic fatty liver disease in the elderly: results from the Rotterdam study. J Hepatol. 2012;57(6):1305-11.

50. Wong RJ, Ahmed A. Obesity and non-alcoholic fatty liver disease: Disparate associations among Asian populations. World J Hepatol. 2014;6(5):263-73.

\section{Tables}


Table 1

Baseline characteristics of the study sample, stratified according to the combination of obesity (O), abdominal obesity (AO), and NAFLD prese

\section{Non-obese}

\section{Obese}

\begin{tabular}{|c|c|c|c|c|c|c|c|c|c|c|c|}
\hline & $A O(-)$ & & & $\mathrm{AO}(+)$ & & & $\mathrm{AO}(-)$ & & & $\mathrm{AO}(+)$ & \\
\hline Variable & $\begin{array}{l}\text { NAFLD(-) } \\
(\mathrm{N}= \\
3,498)\end{array}$ & $\begin{array}{l}\text { NAFLD(+) } \\
(\mathrm{N}=869)\end{array}$ & $\begin{array}{l}\mathrm{P}- \\
\text { value }\end{array}$ & $\begin{array}{l}\text { NAFLD(-) } \\
(\mathrm{N}=166)\end{array}$ & $\begin{array}{l}\text { NAFLD(+) } \\
(\mathrm{N}=\mathbf{3 0 9})\end{array}$ & $\begin{array}{l}\mathrm{P}- \\
\text { value }\end{array}$ & $\begin{array}{l}\text { NAFLD(-) } \\
(\mathrm{N}=557)\end{array}$ & $\begin{array}{l}\text { NAFLD(+) } \\
(\mathrm{N}=992)\end{array}$ & $\begin{array}{l}\mathrm{P}- \\
\text { value }\end{array}$ & $\begin{array}{l}\text { NAFLD(-) } \\
(\mathrm{N}=91)\end{array}$ & $\begin{array}{l}1 \\
1 \\
1\end{array}$ \\
\hline Age, years & $51.4 \pm 9.0$ & $53.2 \pm 9.0$ & $\begin{array}{l}<.001 \\
0.00\end{array}$ & $55.9 \pm 9.2$ & $57.9 \pm 8.2$ & 0.020 & $48.9 \pm 7.5$ & $49.5 \pm 7.5$ & 0.170 & $54.1 \pm 8.4$ & 5 \\
\hline Sex & & & $<.001$ & & & 0.678 & & & $\begin{array}{l}< \\
0.001\end{array}$ & & \\
\hline Male & $\begin{array}{l}1674 \\
(47.9)\end{array}$ & $\begin{array}{l}588 \\
(67.7)\end{array}$ & & $26(15.7)$ & 53 (17.2) & & $\begin{array}{l}229 \\
(41.1)\end{array}$ & $\begin{array}{l}550 \\
(55.4)\end{array}$ & & $31(34.1)$ & $\begin{array}{l}6 \\
(\vdots\end{array}$ \\
\hline Female & $\begin{array}{l}1824 \\
(52.1)\end{array}$ & $\begin{array}{l}281 \\
(32.3)\end{array}$ & & $\begin{array}{l}140 \\
(84.3)\end{array}$ & $\begin{array}{l}256 \\
(82.8)\end{array}$ & & $\begin{array}{l}328 \\
(58.9)\end{array}$ & $\begin{array}{l}442 \\
(44.6)\end{array}$ & & $60(65.9)$ & $\begin{array}{l}1 \\
(t\end{array}$ \\
\hline Area & & & $<001$ & & & 0.073 & & & 0.324 & & \\
\hline Anseong & $\begin{array}{l}1705 \\
(48.7)\end{array}$ & $\begin{array}{l}490 \\
(56.4)\end{array}$ & & $\begin{array}{l}113 \\
(68.1)\end{array}$ & $\begin{array}{l}234 \\
(75.7)\end{array}$ & & $\begin{array}{l}171 \\
(30.7)\end{array}$ & $\begin{array}{l}281 \\
(28.3)\end{array}$ & & $69(75.8)$ & $\begin{array}{l}1 \\
(4\end{array}$ \\
\hline Ansan & $\begin{array}{l}1793 \\
(51.3)\end{array}$ & $\begin{array}{l}379 \\
(43.6)\end{array}$ & & 53 (31.9) & 75 (24.3) & & $\begin{array}{l}386 \\
(69.3)\end{array}$ & $\begin{array}{l}711 \\
(71.7)\end{array}$ & & $22(24.2)$ & $\begin{array}{l}6 \\
(\vdots\end{array}$ \\
\hline
\end{tabular}

Income, 1,000

0.004

0.111

0.616

Won

\begin{tabular}{|c|c|c|c|c|c|c|c|c|c|c|}
\hline$<1,500$ & $\begin{array}{l}1664 \\
(48.4)\end{array}$ & $\begin{array}{l}463 \\
(54.0)\end{array}$ & & $\begin{array}{l}108 \\
(67.9)\end{array}$ & $\begin{array}{l}224 \\
(74.9)\end{array}$ & & $\begin{array}{l}200 \\
(36.4)\end{array}$ & $\begin{array}{l}341 \\
(35.1)\end{array}$ & & $53(60.9)$ \\
\hline$\geq 1,500$ & $\begin{array}{l}1774 \\
(51.6)\end{array}$ & $\begin{array}{l}395 \\
(46.0)\end{array}$ & & $51(32.1)$ & 75 (25.1) & & $\begin{array}{l}350 \\
(63.6)\end{array}$ & $\begin{array}{l}631 \\
(64.9)\end{array}$ & & $34(39.1)$ \\
\hline BMI, $\mathrm{kg} / \mathrm{m}^{2}$ & $22.1 \pm 1.9$ & $23.4 \pm 1.4$ & $\begin{array}{l}< \\
0.001\end{array}$ & $23.3 \pm 1.2$ & $24.0 \pm 0.9$ & $\begin{array}{l}< \\
0.001\end{array}$ & $26.0 \pm 0.9$ & $26.7 \pm 1.3$ & $\begin{array}{l}< \\
0.001\end{array}$ & $26.3 \pm 1.0$ \\
\hline $\begin{array}{l}\text { Waist } \\
\text { circumference, }\end{array}$ & $75.5 \pm 5.9$ & $81.9 \pm 4.2$ & $\begin{array}{l}< \\
0.001\end{array}$ & $88.4 \pm 2.9$ & $89.8 \pm 3.3$ & $\begin{array}{l}< \\
0.001\end{array}$ & $80.9 \pm 4.4$ & $84.0 \pm 3.6$ & $\begin{array}{l}< \\
0.001\end{array}$ & $89.0 \pm 2.6$ \\
\hline
\end{tabular}

$\mathrm{cm}$

\begin{tabular}{|c|c|c|c|c|c|c|c|c|c|c|}
\hline $\mathrm{SBP}, \mathrm{mmHg}$ & $\begin{array}{l}116.3 \pm \\
17.3\end{array}$ & $\begin{array}{l}124.6 \pm \\
18.2\end{array}$ & $<.001$ & $\begin{array}{l}123.8 \pm \\
18.7\end{array}$ & $\begin{array}{l}126.0 \pm \\
18.1\end{array}$ & 0.200 & $\begin{array}{l}117.3 \pm \\
17.4\end{array}$ & $\begin{array}{l}121.6 \pm \\
16.9\end{array}$ & $<.001$ & $\begin{array}{l}120.0 \pm \\
13.8\end{array}$ \\
\hline $\mathrm{DBP}, \mathrm{mmHg}$ & $\begin{array}{l}76.8 \pm \\
10.8\end{array}$ & $\begin{array}{l}82.1 \pm \\
10.8\end{array}$ & $<.001$ & $\begin{array}{l}80.5 \pm \\
12.3\end{array}$ & $\begin{array}{l}80.9 \pm \\
11.2\end{array}$ & 0.739 & $\begin{array}{l}78.2 \pm \\
11.1\end{array}$ & $\begin{array}{l}81.7 \pm \\
11.1\end{array}$ & $<.001$ & $79.8 \pm 9.1$ \\
\hline Hypertension & $\begin{array}{l}627 \\
(17.9)\end{array}$ & $\begin{array}{l}313 \\
(36.0)\end{array}$ & $\begin{array}{l}<.001 \\
0.00\end{array}$ & $51(30.7)$ & $\begin{array}{l}113 \\
(36.6)\end{array}$ & 0.201 & $\begin{array}{l}123 \\
(22.1)\end{array}$ & $\begin{array}{l}328 \\
(33.1)\end{array}$ & $\dot{0} 001$ & 19 (20.9) \\
\hline $\begin{array}{l}\text { Diabetes } \\
\text { mellitus }\end{array}$ & $173(5.0)$ & $\begin{array}{l}149 \\
(17.1)\end{array}$ & $\begin{array}{l}< \\
0.001\end{array}$ & $14(8.4)$ & 61 (19.7) & 0.001 & $21(3.8)$ & $\begin{array}{l}114 \\
(11.5)\end{array}$ & $\begin{array}{l}< \\
0.001\end{array}$ & $5(5.5)$ \\
\hline Hyperlipidemia & $49(1.4)$ & $34(3.9)$ & $\begin{array}{l}< \\
0.001\end{array}$ & $1(0.6)$ & $8(2.6)$ & 0.130 & $9(1.6)$ & $41(4.1)$ & 0.007 & $1(1.1)$ \\
\hline Kidney disease & $91(2.6)$ & $24(2.8)$ & 0.795 & $6(3.6)$ & $17(5.5)$ & 0.361 & $8(1.4)$ & $34(3.4)$ & 0.021 & $2(2.2)$ \\
\hline $\begin{array}{l}\text { Fasting } \\
\text { glucose, } \\
\mathrm{mg} / \mathrm{dL}\end{array}$ & $\begin{array}{l}83.1 \pm \\
14.7\end{array}$ & $\begin{array}{l}91.9 \pm \\
31.0\end{array}$ & $<.001$ & $\begin{array}{l}82.4 \pm \\
13.4\end{array}$ & $\begin{array}{l}88.6 \pm \\
26.8\end{array}$ & 0.001 & $\begin{array}{l}83.9 \pm \\
12.7\end{array}$ & $\begin{array}{l}89.7 \pm \\
23.0\end{array}$ & $\begin{array}{l}<.001 \\
0.00\end{array}$ & $83.6 \pm 9.1$ \\
\hline Albumin, $\mathrm{g} / \mathrm{dL}$ & $4.2 \pm 0.3$ & $4.3 \pm 0.3$ & $\hat{0}_{0.001}$ & $4.1 \pm 0.2$ & $4.1 \pm 0.3$ & 0.390 & $4.2 \pm 0.3$ & $4.3 \pm 0.3$ & $<.001$ & $4.2 \pm 0.3$ \\
\hline BUN, mg/dL & $14.2 \pm 3.7$ & $\begin{array}{l}13.97 \pm \\
3.56\end{array}$ & 0.088 & $\begin{array}{l}15.02 \pm \\
4.30\end{array}$ & $\begin{array}{l}14.39 \pm \\
3.69\end{array}$ & 0.095 & $\begin{array}{l}14.23 \pm \\
3.65\end{array}$ & $\begin{array}{l}14.44 \pm \\
3.60\end{array}$ & 0.276 & $\begin{array}{l}15.18 \pm \\
3.50\end{array}$ \\
\hline $\begin{array}{l}\text { Creatinine, } \\
\mathrm{mg} / \mathrm{dL}\end{array}$ & $0.83 \pm 0.2$ & $0.87 \pm 0.2$ & $<.001$ & $0.80 \pm 0.2$ & $0.78 \pm 0.2$ & 0.274 & $0.84 \pm 0.3$ & $0.87 \pm 0.2$ & 0.025 & $0.82 \pm 0.2$ \\
\hline AST, IU/L & $\begin{array}{l}27.1 \pm \\
10.7\end{array}$ & $\begin{array}{l}38.34 \pm \\
37.26\end{array}$ & $<.001$ & $\begin{array}{l}25.04 \pm \\
4.51\end{array}$ & $\begin{array}{l}28.65 \pm \\
12.08\end{array}$ & $\begin{array}{l}< \\
0.001\end{array}$ & $\begin{array}{l}25.85 \pm \\
7.06\end{array}$ & $\begin{array}{l}31.95 \pm \\
27.99\end{array}$ & $\begin{array}{l}< \\
0.001\end{array}$ & $\begin{array}{l}24.55 \pm \\
5.34\end{array}$ \\
\hline
\end{tabular}

Continuous data are reported as means \pm standard deviations and were compared using ANOVA; categorical data are reported as $n(\%)$ and were compared $u$ square test.

AbbreviationsSBP, systolic blood pressure; DBP, diastolic blood pressure; BUN, blood urea nitrogen; AST, aspartate aminotransferase; ALT, alanine aminotrans gamma-glutamyltransferase; HDL, high-density lipoprotein; WBC, white blood cell; RBC, red blood cell. 


\begin{tabular}{|c|c|c|c|c|c|c|c|c|c|c|c|}
\hline & Non-obese & & & & & & Obese & & & & \\
\hline ALT, IU/L & $\begin{array}{l}22.2 \pm \\
15.2\end{array}$ & $\begin{array}{l}39.2 \pm \\
41.5\end{array}$ & $<.001$ & $19.9 \pm 7.0$ & $\begin{array}{l}27.1 \pm \\
15.2\end{array}$ & $\begin{array}{l}< \\
0.001\end{array}$ & $21.7 \pm 8.2$ & $\begin{array}{l}36.0 \pm \\
53.2\end{array}$ & $<.001$ & $\begin{array}{l}21.6 \pm \\
12.4\end{array}$ & $\begin{array}{l}3 \\
2\end{array}$ \\
\hline GGT, IU/L & $\begin{array}{l}19.0 \pm \\
17.8\end{array}$ & $\begin{array}{l}88.4 \pm \\
144.4\end{array}$ & $<0.001$ & $11.8 \pm 4.9$ & $\begin{array}{l}29.7 \pm \\
30.9\end{array}$ & $\begin{array}{l}< \\
0.001\end{array}$ & $15.6 \pm 7.6$ & $\begin{array}{l}43.3 \pm \\
47.8\end{array}$ & $<.001$ & $12.3 \pm 4.7$ & $\begin{array}{l}3 \\
3\end{array}$ \\
\hline $\begin{array}{l}\text { Total } \\
\text { cholesterol, } \\
\mathrm{mg} / \mathrm{dL}\end{array}$ & $\begin{array}{l}183.6 \pm \\
32.3\end{array}$ & $\begin{array}{l}196.7 \pm \\
41.0\end{array}$ & $<.001$ & $\begin{array}{l}179.8 \pm \\
31.2\end{array}$ & $\begin{array}{l}195.4 \pm \\
30.7\end{array}$ & $\begin{array}{l}< \\
0.001\end{array}$ & $\begin{array}{l}183.5 \pm \\
33.1\end{array}$ & $\begin{array}{l}201.0 \pm \\
34.3\end{array}$ & $<.001$ & $\begin{array}{l}184.0 \pm \\
31.1\end{array}$ & $\begin{array}{l}1 \\
3\end{array}$ \\
\hline $\begin{array}{l}\text { HDL- } \\
\text { cholesterol, } \\
\mathrm{mg} / \mathrm{dL}\end{array}$ & $\begin{array}{l}47.4 \pm \\
10.2\end{array}$ & $\begin{array}{l}43.0 \pm \\
10.3\end{array}$ & $<.001$ & $45.2 \pm 9.0$ & $41.7 \pm 9.0$ & $\begin{array}{l}< \\
0.001\end{array}$ & $45.8 \pm 9.4$ & $41.6 \pm 9.0$ & $<.001$ & $\begin{array}{l}45.9 \pm \\
10.6\end{array}$ & 4 \\
\hline $\begin{array}{l}\text { Triglyceride, } \\
\text { mg/dL }\end{array}$ & $\begin{array}{l}117.1 \pm \\
44.3\end{array}$ & $\begin{array}{l}241.6 \pm \\
137.7\end{array}$ & $<.001$ & $\begin{array}{l}111.5 \pm \\
35.7\end{array}$ & $\begin{array}{l}200.6 \pm \\
90.1\end{array}$ & $\begin{array}{l}< \\
0.001\end{array}$ & $\begin{array}{l}104.9 \pm \\
33.2\end{array}$ & $\begin{array}{l}205.1 \pm \\
116.5\end{array}$ & $<.001$ & $\begin{array}{l}91.7 \pm \\
26.2\end{array}$ & $\begin{array}{l}1 \\
1\end{array}$ \\
\hline $\begin{array}{l}\text { Total protein, } \\
\text { g/dL }\end{array}$ & $7.3 \pm 0.4$ & $7.4 \pm 0.5$ & $\begin{array}{l}< \\
0.001\end{array}$ & $7.2 \pm 0.4$ & $7.2 \pm 0.4$ & 0.576 & $7.3 \pm 0.4$ & $7.4 \pm 0.4$ & $<.001$ & $7.2 \pm 0.4$ & 7 \\
\hline $\begin{array}{l}\text { Total bilirubin, } \\
\mathrm{mg} / \mathrm{dL}\end{array}$ & $0.6 \pm 0.3$ & $0.6 \pm 0.3$ & 0.235 & $0.5 \pm 0.2$ & $0.5 \pm 0.3$ & 0.993 & $0.6 \pm 0.3$ & $0.7 \pm 0.3$ & 0.217 & $0.6 \pm 0.3$ & 0 \\
\hline $\begin{array}{l}\text { Calcium, } \\
\mathrm{mg} / \mathrm{dL}\end{array}$ & $9.5 \pm 0.5$ & $9.7 \pm 0.5$ & ¿.001 & $9.6 \pm 0.4$ & $9.7 \pm 0.4$ & 0.018 & $9.5 \pm 0.4$ & $9.7 \pm 0.5$ & <. 001 & $9.5 \pm 0.4$ & 9 \\
\hline $\begin{array}{l}\text { Sodium, } \\
\mathrm{mmol} / \mathrm{L}\end{array}$ & $\begin{array}{l}142.5 \pm \\
2.2\end{array}$ & $\begin{array}{l}142.4 \pm \\
2.4\end{array}$ & 0.183 & $\begin{array}{l}142.6 \pm \\
2.3\end{array}$ & $\begin{array}{l}142.7 \pm \\
2.1\end{array}$ & 0.590 & $\begin{array}{l}142.5 \pm \\
2.2\end{array}$ & $\begin{array}{l}142.8 \pm \\
2.1\end{array}$ & 0.003 & $\begin{array}{l}142.6 \pm \\
1.9\end{array}$ & $\begin{array}{l}1 \\
2\end{array}$ \\
\hline $\begin{array}{l}\text { Potassium, } \\
\mathrm{mmol} / \mathrm{L}\end{array}$ & $4.5 \pm 0.4$ & $4.5 \pm 0.4$ & 0.606 & $4.5 \pm 0.4$ & $4.5 \pm 0.4$ & 0.515 & $4.4 \pm 0.4$ & $4.5 \pm 0.4$ & 0.006 & $4.5 \pm 0.4$ & 4 \\
\hline $\begin{array}{l}\text { Chloride, } \\
\mathrm{mmol} / \mathrm{L}\end{array}$ & $\begin{array}{l}103.1 \pm \\
2.3\end{array}$ & $\begin{array}{l}102.5 \pm \\
2.6\end{array}$ & $<.001$ & $\begin{array}{l}103.6 \pm \\
2.3\end{array}$ & $\begin{array}{l}102.9 \pm \\
2.3\end{array}$ & 0.002 & $\begin{array}{l}103.3 \pm \\
2.1\end{array}$ & $\begin{array}{l}102.8 \pm \\
2.3\end{array}$ & $<.001$ & $\begin{array}{l}103.8 \pm \\
2.0\end{array}$ & $\begin{array}{l}1 \\
2\end{array}$ \\
\hline $\begin{array}{l}\text { C-reactive } \\
\text { protein, } \mathrm{mg} / \mathrm{dL}\end{array}$ & $\begin{array}{l}0.20 \pm \\
0.50\end{array}$ & $\begin{array}{l}0.26 \pm \\
0.60\end{array}$ & 0.003 & $\begin{array}{l}0.16 \pm \\
0.19\end{array}$ & $\begin{array}{l}0.34 \pm \\
1.42\end{array}$ & 0.022 & $\begin{array}{l}0.18 \pm \\
0.36\end{array}$ & $\begin{array}{l}0.25 \pm \\
0.39\end{array}$ & $\begin{array}{l}<.001 \\
0.00\end{array}$ & $\begin{array}{l}0.19 \pm \\
0.27\end{array}$ & $\begin{array}{l}0 \\
0\end{array}$ \\
\hline $\begin{array}{l}\text { WBC count, } \\
10^{3} / \mu \mathrm{L}\end{array}$ & $6.2 \pm 1.8$ & $7.0 \pm 2.0$ & $\begin{array}{l}< \\
0.001\end{array}$ & $5.9 \pm 1.5$ & $6.5 \pm 1.8$ & $\begin{array}{l}<.001 \\
0 .\end{array}$ & $6.3 \pm 1.7$ & $6.8 \pm 1.7$ & $\begin{array}{l}< \\
0.001\end{array}$ & $5.9 \pm 1.6$ & 6 \\
\hline $\begin{array}{l}\text { RBC count, } \\
10^{6} / \mu \mathrm{L}\end{array}$ & $4.3 \pm 0.5$ & $4.5 \pm 0.5$ & $\begin{array}{l}<.001 \\
0\end{array}$ & $4.2 \pm 0.4$ & $4.3 \pm 0.4$ & 0.004 & $4.4 \pm 0.5$ & $4.6 \pm 0.5$ & $\begin{array}{l}< \\
0.001\end{array}$ & $4.4 \pm 0.5$ & 4 \\
\hline $\begin{array}{l}\text { Hemoglobin, } \\
\mathrm{g} / \mathrm{dL}\end{array}$ & $13.3 \pm 1.6$ & $14.2 \pm 1.5$ & $\begin{array}{l}< \\
0.001\end{array}$ & $12.7 \pm 1.3$ & $13.1 \pm 1.2$ & $\dot{0} 001$ & $13.3 \pm 1.6$ & $14.1 \pm 1.6$ & $\dot{0} 001$ & $13.1 \pm 1.6$ & 1 \\
\hline Hematocrit, \% & $40.4 \pm 4.5$ & $42.6 \pm 4.4$ & $\dot{0} 001$ & $38.7 \pm 3.6$ & $39.7 \pm 3.5$ & 0.002 & $40.0 \pm 4.4$ & $42.1 \pm 4.6$ & $\begin{array}{l}<.001 \\
0.00\end{array}$ & $39.9 \pm 4.5$ & 4 \\
\hline HbA1c, \% & $5.6 \pm 0.7$ & $6.0 \pm 1.2$ & <.001 & $5.6 \pm 0.9$ & $6.1 \pm 1.3$ & $<.001$ & $5.6 \pm 0.6$ & $5.9 \pm 0.9$ & $<.001$ & $5.6 \pm 0.4$ & 6 \\
\hline $\begin{array}{l}\text { Platelet count, } \\
10^{3} / \mu \mathrm{L}\end{array}$ & $\begin{array}{l}259.3 \pm \\
61.2\end{array}$ & $\begin{array}{l}271.0 \pm \\
71.9\end{array}$ & $\hat{0}_{0.001}$ & $\begin{array}{l}254.9 \pm \\
59.6\end{array}$ & $\begin{array}{l}272.0 \pm \\
62.6\end{array}$ & 0.004 & $\begin{array}{l}264.3 \pm \\
59.9\end{array}$ & $\begin{array}{l}271.9 \pm \\
63.2\end{array}$ & 0.020 & $\begin{array}{l}267.0 \pm \\
60.2\end{array}$ & $\begin{array}{l}2 \\
6\end{array}$ \\
\hline $\begin{array}{l}\text { Renin, } \\
\mathrm{ng} / \mathrm{mL} / \mathrm{hr}\end{array}$ & $2.7 \pm 2.5$ & $3.4 \pm 3.7$ & $<.001$ & $1.6 \pm 1.6$ & $2.5 \pm 4.3$ & 0.001 & $2.5 \pm 2.9$ & $2.7 \pm 3.0$ & 0.158 & $1.9 \pm 2.0$ & 2 \\
\hline Drinking & & & $<.001$ & & & 0.983 & & & 0.004 & & \\
\hline Non-drinker & $\begin{array}{l}1697 \\
(48.9)\end{array}$ & $\begin{array}{l}238 \\
(27.5)\end{array}$ & & $\begin{array}{l}106 \\
(65.8)\end{array}$ & $\begin{array}{l}198 \\
(65.1)\end{array}$ & & $\begin{array}{l}261 \\
(47.2)\end{array}$ & $\begin{array}{l}394 \\
(39.9)\end{array}$ & & 54 (59.3) & $\begin{array}{l}1 \\
(!\end{array}$ \\
\hline Ex-drinker & $237(6.8)$ & $55(6.4)$ & & $6(3.7)$ & $11(3.6)$ & & $40(7.2)$ & $57(5.8)$ & & $10(11.0)$ & 1 \\
\hline Current drinker & $\begin{array}{l}1,535 \\
(44.2)\end{array}$ & $\begin{array}{l}571 \\
(66.1)\end{array}$ & & 49 (30.4) & $95(31.3)$ & & $\begin{array}{l}252 \\
(45.6)\end{array}$ & $\begin{array}{l}536 \\
(54.3)\end{array}$ & & 27 (29.7) & $\begin{array}{l}7 \\
(\vdots\end{array}$ \\
\hline Smoking & & & $\begin{array}{l}<.001 \\
0.01\end{array}$ & & & 0.433 & & & $<.001$ & & \\
\hline Non-smoker & $\begin{array}{l}2,064 \\
(59.7)\end{array}$ & $\begin{array}{l}342 \\
(39.6)\end{array}$ & & $\begin{array}{l}139 \\
(85.8)\end{array}$ & $\begin{array}{l}246 \\
(81.2)\end{array}$ & & $\begin{array}{l}381 \\
(69.0)\end{array}$ & $\begin{array}{l}505 \\
(51.7)\end{array}$ & & 70 (76.9) & $\begin{array}{l}1 \\
(t\end{array}$ \\
\hline Ex-smoker & $\begin{array}{l}511 \\
(14.8)\end{array}$ & $\begin{array}{l}174 \\
(20.2)\end{array}$ & & $11(6.8)$ & $25(8.3)$ & & $86(15.6)$ & $\begin{array}{l}189 \\
(19.3)\end{array}$ & & $12(13.2)$ & $\begin{array}{l}2 \\
(\end{array}$ \\
\hline
\end{tabular}

Continuous data are reported as means \pm standard deviations and were compared using ANOVA; categorical data are reported as $n(\%)$ and were compared $u$ square test.

AbbreviationsSBP, systolic blood pressure; DBP, diastolic blood pressure; BUN, blood urea nitrogen; AST, aspartate aminotransferase; ALT, alanine aminotrans gamma-glutamyltransferase; HDL, high-density lipoprotein; WBC, white blood cell; RBC, red blood cell. 


\begin{tabular}{|lllllll}
\hline \multicolumn{3}{c}{ Non-obese } & & \multicolumn{2}{c}{ Obese } \\
\hline $\begin{array}{l}\text { Current } \\
\text { smoker }\end{array}$ & 881 & 347 & $12(7.4)$ & $32(10.6)$ & $85(15.4)$ & 283 \\
$(29.0)$ & $3(9.9)$ & 3. \\
\hline
\end{tabular}

Continuous data are reported as means \pm standard deviations and were compared using ANOVA; categorical data are reported as $\mathrm{n}(\%)$ and were compared $\mathrm{u}$ square test.

AbbreviationsSBP, systolic blood pressure; DBP, diastolic blood pressure; BUN, blood urea nitrogen; AST, aspartate aminotransferase; ALT, alanine aminotrans gamma-glutamyltransferase; HDL, high-density lipoprotein; WBC, white blood cell; RBC, red blood cell.

\section{Figures}

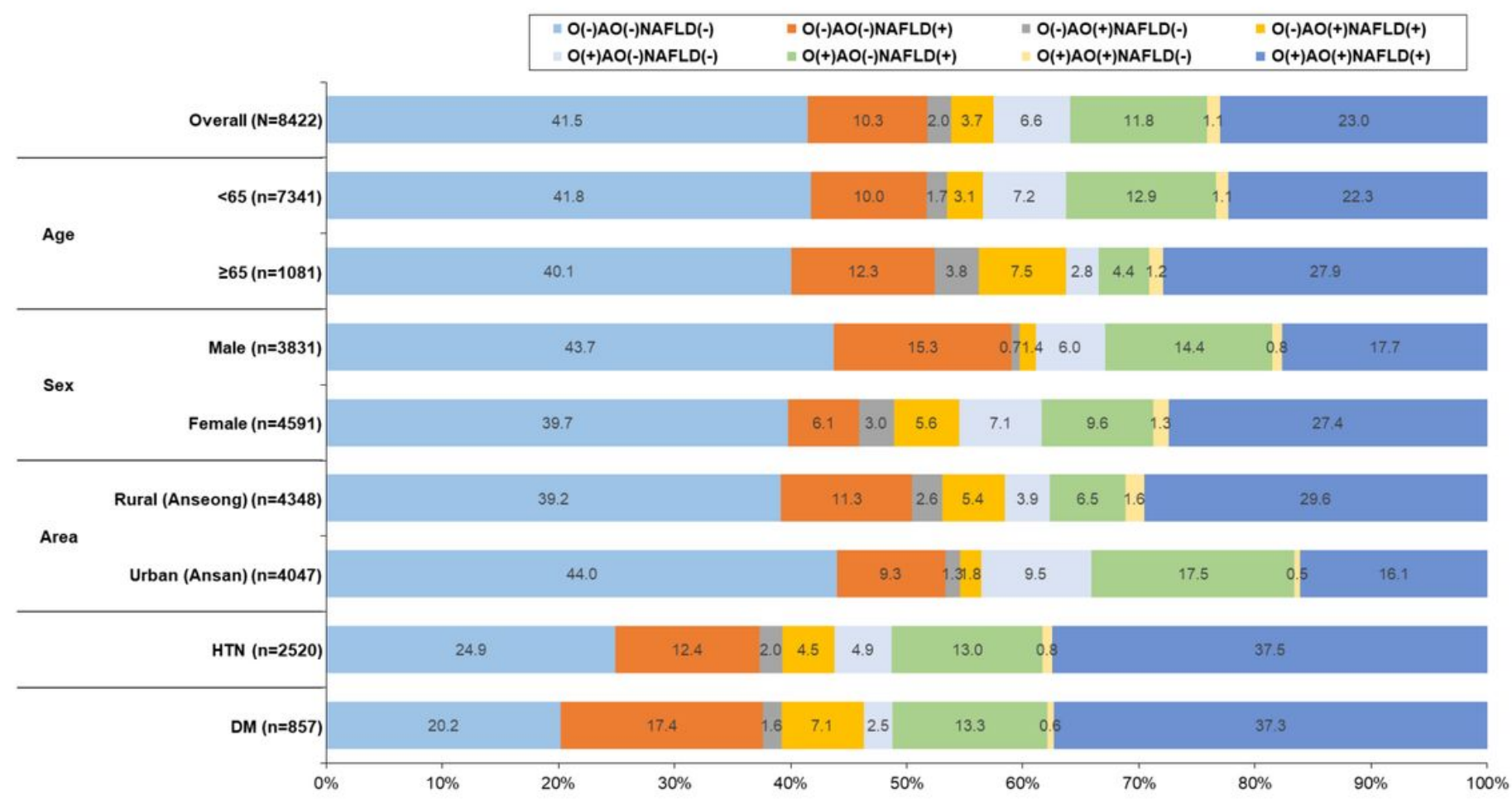

Data are represented as percentages (\%).

Abbreviations: NAFLD, non-alcoholic fatty liver disease CVD, cardiovascular disease; $\mathrm{O}(-) \mathrm{AO}(-) \mathrm{NAFLD}(-)$, no obesity, abdominal obesity, or NAFLD;

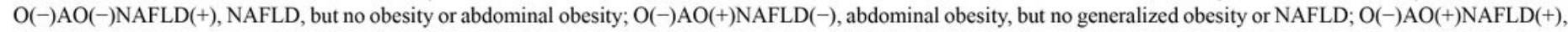
abdominal obesity and NAFLD, but no generalized obesity; O(+)AO(-)NAFLD $(-)$, obesity, but no abdominal obesity or NAFLD; O(+)AO(-)NAFLD(+), obesity and NAFLD, but no abdominal obesity; $\mathrm{O}(+) \mathrm{AO}(+) \mathrm{NAFLD}(-)$, obesity and abdominal obesity, but no NAFLD; $\mathrm{O}(+) \mathrm{AO}(+) \mathrm{NAFLD}(+)$, obesity, abdominal obesity, and NAFLD; HTN, hypertension; DM, diabetes mellitus.

\section{Figure 1}

Distribution of the combinations of obesity, abdominal obesity, and NAFLD 


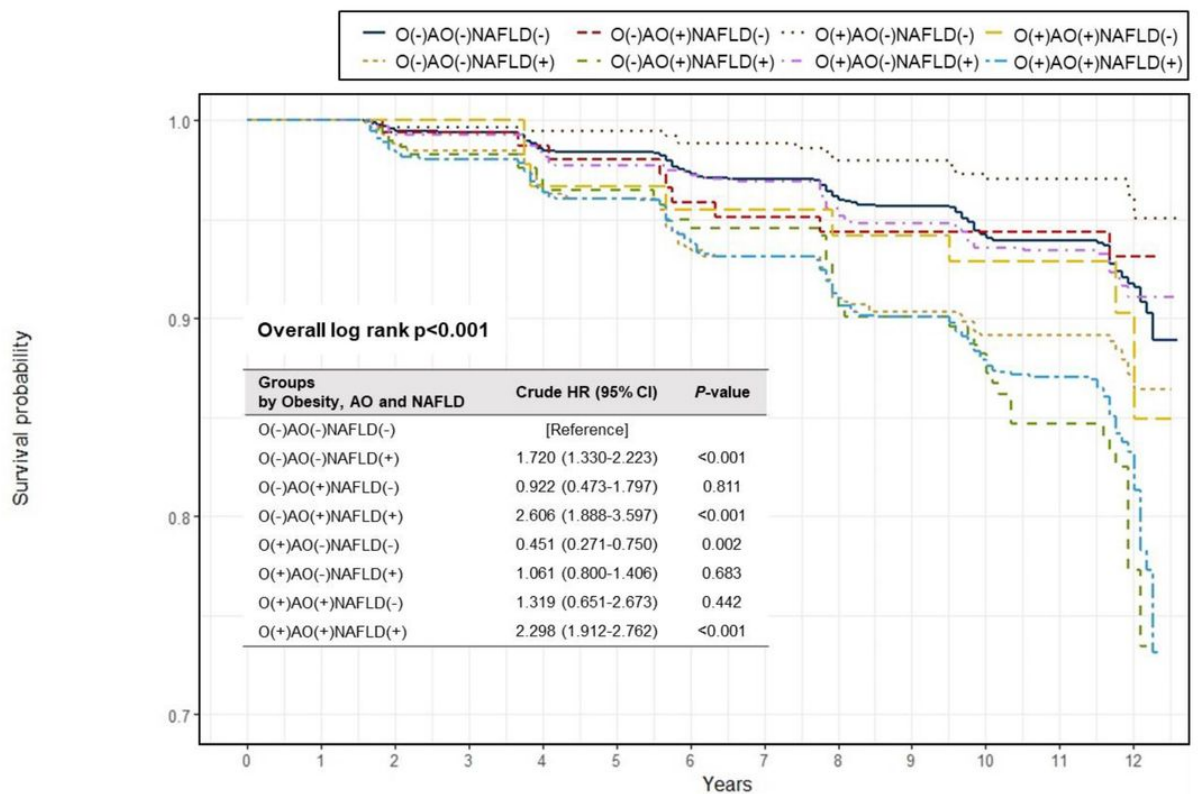

Number at risk

\begin{tabular}{|c|c|c|c|c|c|c|c|c|c|c|c|c|c|}
\hline \multirow{2}{*}{$\begin{array}{l}\mathrm{O}(-) \mathrm{AO}(-) \operatorname{NAFLD}(-) \\
\mathrm{O}(-) \mathrm{AO}(-) \operatorname{NAFLD}(+)\end{array}$} & 3498 & 3498 & 3290 & 3185 & 3019 & 2942 & 2833 & 2781 & 2636 & 2550 & 2287 & 2196 & 469 \\
\hline & 869 & 869 & 805 & 771 & 709 & 683 & 640 & 619 & 576 & 551 & 485 & 471 & 111 \\
\hline $\mathrm{O}(-) \mathrm{AO}(+)$ NAFLD(-) & 166 & 166 & 158 & 152 & 140 & 137 & 128 & 126 & 120 & 116 & 104 & 97 & 21 \\
\hline $\mathrm{O}(-) \mathrm{AO}(+) \operatorname{NAFLD}(+)-$ & 309 & 309 & 284 & 277 & 263 & 256 & 245 & 239 & 220 & 209 & 177 & 165 & 33 \\
\hline $\mathrm{O}(+) \mathrm{AO}(-)$ NAFLD $(-)-$ & 557 & 557 & 525 & 521 & 503 & 495 & 473 & 470 & 450 & 444 & 403 & 398 & 82 \\
\hline $\mathrm{O}\left({ }^{+}\right) \mathrm{AO}(-) \mathrm{NAFLD}(+)-$ & 992 & 992 & 940 & 917 & 874 & 860 & 816 & 800 & 760 & 735 & 664 & 643 & 116 \\
\hline $\mathrm{O}(+) \mathrm{AO}(+) \operatorname{NAFLD}(-)-$ & 91 & 91 & 90 & 90 & 84 & 82 & 78 & 78 & 74 & 73 & 66 & 64 & 17 \\
\hline$O\left(^{+}\right) \mathrm{AO}(+) \operatorname{NAFLD}(+)-$ & 1940 & 1940 & 1786 & 1725 & 1609 & 1567 & 1489 & 1452 & 1364 & 1320 & 1176 & 1131 & 262 \\
\hline & 0 & 1 & 2 & 3 & 4 & 5 & 6 & 7 & 8 & 9 & 10 & 11 & 12 \\
\hline
\end{tabular}

Abbreviations: CVD, cardiovascular disease; NAFLD, nonalcoholic fatty liver disease; $\mathrm{O}(-) \mathrm{AO}(-) \mathrm{NAFLD}(-)$, no obesity, abdominal obesity, or NAFLD; $\mathrm{O}(-) \mathrm{AO}(-) \mathrm{NAFLD}(+)$, NAFLD, but no obesity or abdominal obesity; $\mathrm{O}(-) \mathrm{AO}(+) \mathrm{NAFLD}(-)$, abdominal obesity, but no generalized obesity or NAFLD; $\mathrm{O}(-) \mathrm{AO}(+) \mathrm{NAFLD}(+)$, abdominal obesity and NAFLD, but no generalized obesity; $\mathrm{O}(+) \mathrm{AO}(-) \mathrm{NAFLD}(-)$, obesity, but no abdominal obesity or NAFLD; $\mathrm{O}(+) \mathrm{AO}(-) \mathrm{NAFLD}(+)$, obesity and NAFLD, but no abdominal obesity; $\mathrm{O}(+) \mathrm{AO}(+) \mathrm{NAFLD}(-)$, obesity and abdominal obesity, but no NAFLD; $\mathrm{O}(+) \mathrm{AO}(+) \mathrm{NAFLD}(+)$, obesity, abdominal obesity, and NAFLD.

\section{Figure 2}

Kaplan-Meier curves for incident CVD, by the combination of obesity, AO, and NAFLD present 


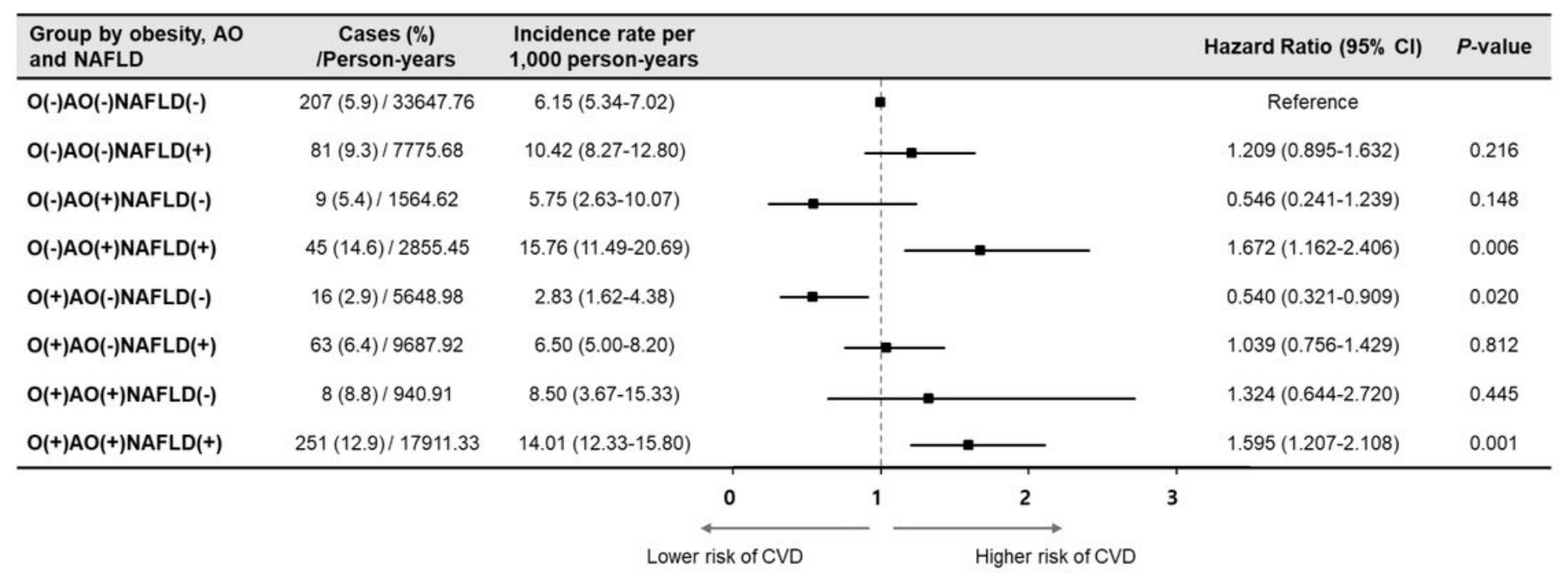

The hazard ratios were adjusted for age, sex, geographical area, income, hip circumference, systolic blood pressure, diastolic blood pressure, hypertension, diabetes mellitus, hyperlipidemia, kidney disease, albumin, BUN, creatinine, AST, ALT, GGT, total cholesterol, triglyceride, total protein, total bilirubin, calcium, sodium, potassium, chloride, C-reactive protein, WBC count, RBC count, hemoglobin, hematocrit, HbAlc, platelet, renin activity, drinking status, and smoking status.

Abbreviations: $\mathrm{CI}$, confidence interval; CVD, cardiovascular disease; NAFLD, non-alcoholic fatty liver disease; $\mathrm{AO}$, abdominal obesity; $\mathrm{O}(-) \mathrm{AO}(-) \mathrm{NAFLD}(-)$, no obesity, abdominal obesity, or NAFLD; $\mathrm{O}(-) \mathrm{AO}(-) \mathrm{NAFLD}(+)$, NAFLD, but no obesity or abdominal obesity; $\mathrm{O}(-) \mathrm{AO}(+) \mathrm{NAFLD}(-)$, abdominal obesity, but no generalized obesity or NAFLD; $\mathrm{O}(-) \mathrm{AO}(+) \mathrm{NAFLD}(+)$, abdominal obesity and NAFLD, but no generalized obesity; $\mathrm{O}(+) \mathrm{AO}(-) \mathrm{NAFLD}(-)$, obesity, but no abdominal obesity or NAFLD; $\mathrm{O}(+) \mathrm{AO}(-) \mathrm{NAFLD}(+)$, obesity and NAFLD, but no abdominal obesity; $\mathrm{O}(+) \mathrm{AO}(+) \mathrm{NAFLD}(-)$, obesity and abdominal obesity, but no NAFLD; $\mathrm{O}(+) \mathrm{AO}(+) \mathrm{NAFLD}(+)$, obesity, abdominal obesity, and NAFLD.

Figure 3

Risks of cardiovascular disease associated with the various combinations of obesity, abdominal obesity, and NAFLD

\section{Supplementary Files}

This is a list of supplementary files associated with this preprint. Click to download.

- Addtionalfile1.pdf

- Additionalfile2.pdf

- Additionalfile3.pdf

- Additionalfile4.pdf

- Additionalfile5.pdf 